\title{
9. Apprenticeship in England
}

Patrick Wallis

In 1766, Sir William Blackstone gave the following definition of apprenticeship in his influential treatise on the English common law:

'Another species of servants are called apprentices (from apprendre, to learn) and are usually bound for a term of years, by deed indented or indentures, to serve their masters, and be maintained and instructed by them... This is usually done to persons of trade, in order to learn their art and mystery. ${ }^{1}$

Blackstone's definition offers a useful starting point for an investigation of apprenticeship in early modern England. Most historical, anthropological or economic analyses of apprenticeship would recognise Blackstone's description of apprenticeship as the exchange of labour services for maintenance and instruction. Apprenticeship was then, as it remains, the primary mode of vocational training, allowing workers to fund their education in general skills by taking a lower wage (in England then, usually just food and lodging). It is a system used for trade -- not agriculture. But Blackstone's definition also highlights aspects of apprenticeship that were more specific to England. To him, apprenticeship requires a long term ('of years'), a formal written contract in a specific form ('indentures'), and maintenance as well as instruction. Apprentices are servants, but of a particular kind.

That Blackstone discussed apprentices in a commentary on law is also significant. For among the variety of forms of service that existed in England, apprenticeship was understood as a distinct legal practice. Apprenticeship was tied to a particular contractual form and duration. It placed youths in a specific legal position of formal subordination. From the 1560s to the early 1800s, experiences of service sometimes shaded into each other -- domestic servants picked up craft skills, apprentices hauled water and swept floors. However, in city halls and guild meetings, in Quarter Sessions and Parliament, the status of apprenticeship was understood to be unique. The reasons for this arguably had little do with the needs of apprentices or masters, and instead reflected the functions that apprenticeship had been assigned as the basis for exclusive claims to welfare rights, guild membership, citizenship and the right to practice an occupation.

One legacy of the legal significance of English apprenticeship is the enormous volume of records that survive. Apprenticeship was registered, taxed, examined and monitored. Each step left a paper trail. We probably have more information about apprentices in England than in any other pre-modern state. In part because of this, it has a long, rich historiography that has examined a range of issues, from the guilds' ability to protect child labour, to the socialization of youths, and, recently, the efficiency of human capital formation

\footnotetext{
${ }^{1}$ William Blackstone, Commentaries on the Laws of England (Dublin: John Exshaw, 1766), I, 414. 
and its contribution to England's distinctive early industrialisation. ${ }^{2}$ Thanks to the work of many historians, notably Cliff Webb, large volumes of apprenticeship records are now digitised, allowing us to see how apprenticeship operated in practice. In this chapter, I examine the political economy, scale and distribution, relation to family strategies, openness, and local institutions of apprenticeship. Several broader questions underlie my discussion. Was apprenticeship in England an institution that embedded inequality, redistributing rents to insiders? Was it, alternatively, an unusually efficient system of training? Did guilds somehow sustain apprenticeship? And, throughout, the issue of to what extent was English apprenticeship different to that found elsewhere in Europe?

\section{The Framework of Service}

In the history of English apprenticeship, one moment stands out: the passing of the Statute of Artificers in $1562 .{ }^{3}$ From that date until its repeal in 1814, a completed seven-year apprenticeship was a legal requirement to work in most crafts or trades. No equivalent restriction applied in agriculture. No similar national law existed elsewhere in Europe.

From 1562, the institutional space in which apprenticeship existed was defined by three sets of actors: guilds, town and city governments, and - because of the Statute magistrates. Not all existed in all locations. Independent magistrates were the only relevant authority in rural areas. Guilds operated in many towns and cities in the sixteenth century, but the scale of their activities often declined in the eighteenth century - although the exact chronology of their weakening remains unclear. Urban governments had a long-standing interest in apprenticeship and, outside of London and a few other cities, defined the role of guilds that operated under their sufferance and supervision, while city governors sat as magistrates in their own courts.

To say that the Statute invented an English system of apprenticeship would be a mistake. Certainly this was not its intention. The authors of the law aimed to keep labour on the land. To the crown and a Parliament dominated by large landowners, abundant cheap farm labour and social stability were both appealing targets. The Statute expanded upon earlier laws that sought to stop the rural poor from becoming urban artisans. Its

\footnotetext{
${ }^{2}$ The literature on English apprenticeship is extensive, but only two surveys exist: O.J. Dunlop and R.D Denman, English Apprenticeship and Child Labor (London: T. F. Unwin, 1912), and J. Lane, Apprenticeship in England, 1600-1914 (London: UCL Press, 1996). Important studies that have highlighted key themes include: S.R. Smith, 'The London apprentices as seventeenth-century adolescents', Past and Present 61 (1973), 149-61; C.W. Brooks, 'Apprenticeship, social mobility, and the middling sort, 1550-1800', in: J. Barry and C.W. Brooks (eds.), The Middling Sort of People: Culture, Society, and Politics in England, 1550-1800 (Basingstoke: Macmillan, 1994), 52-83; P. Griffiths, Youth and Authority: Formative Experiences in England, 1560-1640 (Oxford: Clarendon Press, 1996); M. Pelling, 'Apprenticeship, health, and social cohesion in early modern London', History Workshop Journal 37 (1994), 33-56; Joel Mokyr, The Enlightened Economy: An Economic History of Britain, 1700-1850 (New Haven: Yale University Press, 2009); Morgan Kelly, Joel Mokyr, and Cormac O'Grada, 'Precocious Albion: A New Interpretation of the British Industrial Revolution,' Annual Review of Economics 6, (2014). J. Humphries, 'English apprenticeship: A neglected factor in the First Industrial Revolution', in: P. David and M. Thomas (eds.), The Economic Future in Historical Perspective (Oxford: Oxford University Press, 2003), 73-102; Jane Humphries, Childhood and Child Labour in the British Industrial Revolution (Cambridge: Cambridge University Press, 2010); N.E. Feldman and K. van der Beek, 'Skill choice and skill complementarity in eighteenth century England', Explorations in Economic History 59 (2016), 94-113. ${ }^{3}$ See D. Woodward, 'The Background to the Statute of Artificiers: The Genesis of Labour Policy, 1558-63,' Economic History Review, (1981), and more generally Simon Deakin and Frank Wilkinson, The Law of the Labour Market: Industrialization, Employment and Legal Evolution (Oxford: Oxford University Press, 2005).
} 
apprenticeship clauses were designed to limit occupational and geographical mobility. For example, only those with land worth 40 shillings a year could apprentice their children to 'merchants, Mercer, Draper, Goldsmith, Ironmonger, Imbroiderer or Clothier' in corporate towns. $^{4}$

Ironically, the effect of the Statute was probably the opposite of Parliament's intentions. By raising a protective barrier around artisanal labour, it increased the incentives to enter a craft or trade. What constituted an apprenticeship was not even closely examined within the Statute; instead it generalized the 'custom of London'. The mode of the metropolis was made the manner of the nation. The Statute's most visible consequence was fixing the long seven-year minimum term. This remained the English norm into the nineteenth century. Elsewhere, terms were generally shorter and variable. It also generalized a single form of contract, one narrower and less flexible than the more open, individualized agreements used elsewhere in Europe.

The three most distinctive consequences of the Statute of Artificers lay outside the cities. Firstly, one urban form of apprenticeship now applied nationwide: rural artisans were subject to the same contract and rules as those in Norwich or London. Secondly, a completed apprenticeship became a nationwide qualification. Seven years of service established one's right to work. In contrast, England's guilds and cities usually demanded that an apprenticeship be served locally, to a citizen or freemen, to qualify for guild membership (these rules remained after 1567, limiting the Statute's effect in towns, and marked an important difference to much of Europe). Thirdly, the Statute put the policing of apprenticeship into the hands of England's magistrates. Justices of the Peace would thereafter judge disputes between masters and apprentices. In theory, at least, the Statute created a national skilled labour market supervised by the main local agents of the state.

Within England's towns and cities, the Statute of Artificers did not change apprenticeship much in the short term. City and guild ordinances that had been building up since the thirteenth century anticipated its main contents. London's customs had already become a benchmark for urban apprenticeship elsewhere. No national machinery was created to register apprenticeships and ensure compliance; instead enforcement was left to informers bringing law suits to local courts. ${ }^{5}$ There is little evidence that the social limitations the Statute set on entry to apprenticeship were observed; inflation soon pulled their teeth anyway. ${ }^{6}$ It was only from the late seventeenth century onwards, as judges questioned the power of restrictive guild and city by-laws and most guilds lost interest in trade regulation, that the Statute became critical to urban artisans' privileges. Journeymen, rather than guilds, increasingly promoted cases under the Statute to stop individuals who had not served sevenyear apprenticeships from working. ${ }^{7}$ At the same time, the scope of Statute was gradually

\footnotetext{
${ }^{4} 5$ Eliz 1, c. 4, S. 28.

${ }^{5}$ T. K. Derry, 'The Enforcement of a Seven Years Apprenticeship under the Statute of Artificers' (D.Phil. Thesis, University of Oxford, 1930); M.G Davies, The Enforcement of English Apprenticeship: A Study in Applied Mercantilism, 1563-1642 (Cambridge, MA: Harvard University Press, 1956).

${ }^{6}$ A single instance of a certificate for ownership of lands is noted by A.L. Merson and A.J. Willis, A Calendar of Southampton Apprenticeship Registers, 1609-1740 (Southampton: Southampton Records Series. Vol. 12, 1968), xvii.

${ }^{7}$ Derry, 'Enforcement', 1930. 
whittled back through narrow judicial interpretations that freed a range of trades from its requirements, as laissez faire principles spread through the judiciary. ${ }^{8}$

Inside incorporated cities, town governments and guilds were the primary bodies involved in apprenticeship. Their efforts focused on two areas: monitoring entry and resolving disputes, which is discussed below. Voluminous records survive from guilds and cities' systems to register apprenticeships. These records allowed them to check later claims to access based on service, and to enforce quotas on apprentice taking. At this point, many carried out a simple entry examination, to ensure that only 'suitable' youths entered service. However, the bars to entry they created focused on age, disability, nationality, and - very occasionally - literacy. Parallels to modern educational systems break down here: suitability was based on identity not aptitude. For example, London apprentices must be 'Englishmen born', between 14 and 21 when bound and at least 24 when they finished, and not lame or disabled. Only three London guilds, the Goldsmiths, Barber-Surgeons and Apothecaries, included a requirement for literacy, the latter in Latin. It is hard to say if these bars were tightly enforced. Their impact would have been small, at any rate. Similarly, the fees that guilds and cities charged for registering apprenticeships were generally low. A period in the fourteenth and early fifteenth centuries in which London guilds deployed high fees to restrict apprenticeship had led to Parliament imposing a statutory limit of $2 \mathrm{~s} 6 \mathrm{~d}$ in $1530 .{ }^{9}$ Thereafter, few guilds demanded more. ${ }^{10}$ As in much of Europe, these financial barriers were relatively trivial, equating to less than a week's wages for an unskilled construction worker.

Masters too, faced restrictions from guilds and cities about taking apprentices. These potentially had a bigger effect on the supply of apprenticeship. In cities, masters usually had to be freemen, or freemen's widows, for their apprentices to gain any claim to citizenship or freedom. Most important, though, were guild limits on the numbers of apprentices each could train.

Nearly all guilds set quotas per master on apprentice numbers. Most were low. Only four of twenty-two London guilds surveyed allowed ordinary members more than two apprentices at a time; guild officials usually benefited from an additional spot. The main justification for these rules was to ensure adequate employment for guild members - which, in England, usually included journeymen as well as masters. In 1618, for example, the London Clothworkers successfully petitioned the city for its help in limiting apprentices because 'the multitude' bound recently had led to the 'great increase of the number of' clothworkers, creating 'great misery and want' through lack of work. ${ }^{11}$ Given that apprentices were concentrated in the workshops of a small share of masters (see below), quotas also lowered inequality, making it harder for masters to use apprentices to expand. While these rules surely affected which master apprentices joined - by capping their concentration in certain firms - the sheer volume of apprenticeship that occurred suggests that their main effect was to displace youths into the hands of less desirable masters.

One other distinctive political development affected apprenticeship in early-modern England: the passing of the poor laws in 1598 and 1601. England's poor relief system heavily

\footnotetext{
${ }^{8}$ This process of judicial broadening included recognition of oral contracts, and service without indentures.

${ }^{9} 22$ Hen VIII, c. 4.

${ }^{10}$ A few exceptions can be found in Dunlop and Denman, English Apprenticeship, 164.

${ }^{11}$ JCC, v. 30, f. 396. 
utilized a form of apprenticeship as a welfare strategy. Parishes placed children from poor families into apprenticeships with householders, who would maintain them in exchange for service. The degree to which training was given is unclear. The poor laws envisaged paupers learning 'husbandry and huswifery', and 'menial tasks in the fields' was the lot of most children in the seventeenth century; yet there is also evidence of parishes seeking to ensure youths gained a useful trade. ${ }^{12}$ Generally pauper apprentices were younger, around 9 or 10 years old, and the expectation of menial duties, not learning a skill, means they are not the focus of this chapter.

The poor law had a second implication. Once serving an apprenticeship became one of the 'grounds' for settlement in 1691, apprentices acquired the right to claim relief in the parish in which they trained. This added a further incentive to enter apprenticeship. ${ }^{13}$

The terms of the contract of apprenticeship that were referred to in the Statute of Artificers had developed in London by the thirteenth century. ${ }^{14}$ The master promised instruction and subsistence. The apprentice - normally represented by his father or mother offered service and subordination: he promised to follow orders, avoid taverns, not play at cards or games, to spurn fornication and marriage, work hard, and keep his master's secrets. These moral requirements were strongly stated. However, the details of what was to be learned were not specified. Apprentices' ages and the minimum duration were set by city law and, later, Statute. Masters took all their apprentice's earnings, while paying apprentices wages was banned in London - although some apprentices did receive recompense. ${ }^{15}$ The contract was written twice on the same sheet and then cut, so each copy could be verified by matching the serrated edge (hence its name 'indenture'). Contracts were transferrable with both parties' agreement (and, where relevant, guild or city approval), allowing apprentices to move masters. By the seventeenth century, contracts were pre-printed, with gaps left for the details.

Contracts were formulaic in England. Usually, only one aspect was adjusted to fit the circumstances of each apprenticeship: the size of the material and financial commitment each party made. Most other aspects, notably duration, were essentially fixed by law.

Personalization took different forms. Some masters promised payments in clothing, cash or tools at the end of terms - Gloucester apprentices in the sixteenth century usually received 'double apparel' on completion, for example - giving apprentices an incentive to complete. ${ }^{16}$ Some apprentices' families lowered masters' costs by supplying clothing. This could be a

\footnotetext{
${ }^{12}$ Contrast Steve Hindle, On the Parish? The Micro-Politics of Poor Relief in Rural England C. 1550-1750 (Oxford: Clarendon Press, 2004) with K.D.M. Snell, Annals of the Labouring Poor: Social Change and Agrarian England, 1660-1900 (Cambridge: Cambridge University Press, 1985), 278-84. See also Katrina Honeyman, Child Workers in England, 1780-1820: Parish Apprentices and the Making of the Early Industrial Labour Force (Aldershot: Ashgate, 2007); Alysa Levene, 'Pauper Apprenticeship and the Old Poor Law in London: Feeding the Industrial Economy?,' Economic History Review 63, no. 4 (2010).

${ }^{13}$ Technically, only 40 days service generated a settlement for an apprentice. However, a completed apprenticeship appears to have been an informal norm applied in many circumstances, particularly in the first half of the eighteenth century.

${ }^{14}$ The best account of medieval apprenticeship is: S.R Hovland, 'Apprenticeship in Later Medieval London, c. 1300 - c. 1530', Ph.D. Thesis, University of London, 2006.

${ }^{15}$ For examples: John Rule, Experience of Labour in Eighteenth-Century Industry (London: Croom Helm, 1981); 104; Humphries, Childhood, 276.

${ }^{16}$ Jill Barlow, A Calendar of the Registers of Apprentices of the City of Gloucester, 1595-1700 (Gloucester: Bristol and Gloucestershire Archaeological Society, vol. 14, 2001).
} 
substantial contribution: John Coggs, a stationers' apprentice, went through six pairs of shoes a year, costing almost two pounds of his mother's money in $1703-4 .{ }^{17} \mathrm{~A}$ few families placing children in mercantile and trading businesses entered bonds 'for truth', to secure masters against any losses from the apprentice's neglect or dishonesty.

Most famously, apprentices and their families might pay a fee or 'premium' to their master when they started their training. Premiums were negotiated privately, with no guild or city involvement, and were never necessary for apprenticeship; even in the eighteenth century, large numbers of apprentices did not pay fees, as table 1 shows. The timing of trends in fees is unclear. Payments from masters in the form of clothing, cash and tools at the end of apprentices' terms seem to have declined from 1600 onwards. Apprentices' families may then have become more likely to pay fees: they were frequent enough to attract the eye of the state, which taxed them from $1711^{18}$

Table 9.1. London training premiums, companies, and selected occupations, 1710-1800

\begin{tabular}{llllllll}
\hline & $\begin{array}{l}\text { Paying } \\
\text { premium } \\
\%\end{array}$ & $\begin{array}{l}\text { Average } \\
\text { \% }\end{array}$ & $\begin{array}{l}\text { Sd } \\
£\end{array}$ & $\begin{array}{l}\text { Median } \\
£\end{array}$ & $\begin{array}{l}\text { P10 } \\
£\end{array}$ & $\begin{array}{l}\text { P90 } \\
£\end{array}$ & N \\
& & & & & & & \\
Companies & & & & & & & \\
Apothecaries & 84 & 73 & 36 & 63 & 40 & 105 & 585 \\
Blacksmiths & 23 & 11 & 17 & 6 & 3 & 21 & 2832 \\
Grocers & 53 & 88 & 91 & 60 & 5 & 200 & 705 \\
Plasterers & 28 & 12 & 15 & 7 & 4 & 20 & 683 \\
Stationers & 46 & 36 & 44 & 20 & 5 & 100 & 4428 \\
Turners & 52 & 13 & 15 & 10 & 4 & 26 & 816 \\
Vintners & 30 & 21 & 36 & 11 & 5 & 30 & 1628 \\
Clothworkers & 36 & 36 & 57 & 20 & 5 & 84 & 5862 \\
All companies & 33 & 36 & 54 & 15 & 5 & 100 & 15403 \\
& & & & & & & \\
Occupations & & & & & & & \\
Bookbinder & 43 & 15 & 14 & 10 & 4 & 30 & 879 \\
Bookseller & 47 & 90 & 82 & 70 & 11 & 200 & 714 \\
Druggist & 69 & 203 & 112 & 200 & 100 & 315 & 59 \\
Grocer & 64 & 101 & 94 & 92 & 25 & 200 & 200 \\
Haberdasher & 79 & 61 & 39 & 50 & 21 & 100 & 119 \\
\hline
\end{tabular}

\footnotetext{
${ }^{17}$ Max Beloff, ‘A London Apprentice’s Notebook, 1703-5', History 27, no. 105 (1942). Other examples abound, see: Barlow, Gloucester, xviii; Malcolm Graham, ed, Oxford City Apprentices 1697-1800 (Clarendon Press for the Oxford Historical Society, 1987), xxiii; Merson and Willis, Southampton; Margaret Pelling, The Common Lot: Sickness, Medical Occupations and the Urban Poor in Early Modern England (London: Longmans, 1998), 214-15.

${ }^{18} \mathrm{C}$. Minns and P. Wallis, 'The price of human capital in a pre-industrial economy: Premiums and apprenticeship in $18^{\text {th }}$-century England', Explorations in Economic History 50 (2013), 335-50.
} 


\begin{tabular}{llllllll}
\hline $\begin{array}{l}\text { Instrument } \\
\text { maker }\end{array}$ & 59 & 16 & 19 & 10 & 5 & 30 & 299 \\
Plasterer & 28 & 8 & 4 & 6 & 5 & 15 & 204 \\
Printer & 35 & 21 & 20 & 19 & 4 & 40 & 2691 \\
Stationer & 51 & 79 & 80 & 50 & 10 & 190 & 905 \\
Blacksmith & 17 & 7 & 3 & 7 & 3 & 10 & 53 \\
Turner & 64 & 12 & 7 & 10 & 5 & 25 & 87 \\
Dyer & 37 & 12 & 10 & 10 & 5 & 20 & 251 \\
Tailor & 56 & 14 & 12 & 10 & 5 & 30 & 100 \\
Butcher & 29 & 12 & 8 & 11 & 5 & 21 & 169 \\
Calenderer & 14 & 8 & 8 & 5 & 3 & 14 & 545 \\
Watchmaker & 57 & 17 & 16 & 15 & 5 & 30 & 194 \\
Engraver & 74 & 33 & 28 & 25 & 10 & 60 & 307 \\
\hline
\end{tabular}

Note: The table reports premiums in eight London companies. Panel A is grouped by guild; panel B by master's reported occupation. $\mathrm{N}$ is the total number of observations, including those with zero premiums. The descriptive statistics (cols 3-7) are for observations with positive premiums. Source: Minns and Wallis, 'Price of human capital'.

By altering fees, offering end-payments or negotiating over who paid for maintenance and clothing, masters and apprentices served both to balance supply and demand and provide incentives for completion. In short, within the strictures set by national and local laws, there was an active market for training. ${ }^{19}$ But while premiums and payments offered a price mechanism to clear the market for new apprenticeships, the rigidity and length of the required term created a high opportunity cost that, as we will see, stretched the viability of many contracts.

\section{Incidence}

Apprenticeship occurred on an extraordinarily large scale in early modern England. It was employed across almost the full range of skilled and semi-skilled non-agricultural occupations. For youths looking to a future in industry, trade or services, apprenticeship was a normal step between family and independence as an adult, just as service in husbandry was a conventional stage in a life in agriculture. ${ }^{20}$ But whereas farm service was widely spread, apprenticeship - especially in the sixteenth century - was highly concentrated. Four features stand out about the distribution of apprenticeship: the sheer size and durability of apprenticeship; the centrality of London; the comparatively low levels of apprenticeship in other cities; and the dramatic increase in rural apprenticeship in the eighteenth century. One could say that Parliament's decision to base the Statute of Artificers on the custom of London made sense, given that a big share of apprentices were already subject to those rules.

These key features of the distribution of English apprenticeship are illustrated by Table 2, which reports new estimates for the number of youths starting apprenticeships in

\footnotetext{
${ }^{19}$ Minns and Wallis, Price of human capital'; Feldman and van der Beek, 'Skill choice'.

${ }^{20}$ Ann Kussmaul, Servants in Husbandry in Early Modern England (Cambridge: Cambridge University Press, 1981); Peter Laslett, The World We Have Lost (London: Methuen, 1965). 
England. Columns 1 and 2 give estimates for guild or city-registered apprenticeships in towns and cities around 1600 and 1700 . For London, I extrapolate from existing guild and city records. For other towns, I use estimates of the number of apprentices per thousand people, calculated from surviving registers, and multiply them by the number of cities in each size category. This is obviously a rough and ready approach. It is also, by definition, an underestimate: urban registers under-record the actual numbers of indentures. ${ }^{21}$

Guild and city records become untenable as the foundation for an estimate in the eighteenth century. Many ceased to register apprenticeships, while some growing towns, such as Birmingham and Manchester, were not incorporated and so lacked the infrastructure to record apprenticeships. Fortunately, from 1711 records survive from the Stamp Tax, a levy of between 2.5 and 5 percent on apprenticeship premiums. These records only cover apprenticeships in which the master received a premium. But they extend over the entirety of the country, allowing us to examine rural apprenticeship. Columns 3 and 4 report counts of fee-paying apprentices for the 1710s and 1790s.

Table 9.2. Annual entries to apprenticeship in England, $17^{\text {th }}-18^{\text {th }}$ centuries

\begin{tabular}{|c|c|c|c|c|}
\hline & \multicolumn{2}{|c|}{ Apprentices in Incorporated Cities } & \multicolumn{2}{|c|}{ Apprentices paying Premiums } \\
\hline & c. 1600 & c. 1700 & c. 1710 & c. 1790 \\
\hline \multicolumn{5}{|l|}{ Urban } \\
\hline London & $3,000-4,000$ & c. 4,000 & 1,960 & 1,020 \\
\hline Towns $>10,000$ & $365(162-597)$ & $586(288-1060)$ & 451 & 862 \\
\hline Towns 5,000-10,000 & $484(293-641)$ & $806(488-1068)$ & 443 & 299 \\
\hline Small boroughs & - & - & 602 & 871 \\
\hline Urban Sub-Total & $4,349(3,455-5,238)$ & $5,392(4,776-6,128)$ & 3,458 & 2,610 \\
\hline Rural Sub-Total & - & - & 1,605 & 3,155 \\
\hline Total & - & - & 5,226 & 5,782 \\
\hline $\begin{array}{l}\text { Share of teenage males } \\
(\%)\end{array}$ & $8-13$ & $11-14$ & 11 & 8 \\
\hline $\begin{array}{l}\text { Share of teenage males } \\
\text { outside ag. }(\%)\end{array}$ & $24-37$ & $21-26$ & 20 & 13 \\
\hline
\end{tabular}

Note: Columns $1 \& 2$ are based on the following assumptions. In 1600, aside from London, England had four cities with more than 10,000 inhabitants (Norwich, York, Bristol and Newcastle), and 15 with 5,000 to 10,000. By 1700, 6 towns exceeded 10,000 inhabitants, and 25 had 5,000 to 10,000 (E.A. Wrigley, 'Urban Growth and Agricultural Change: England and the Continent in the Early Modern Period', Journal of Interdisciplinary

\footnotetext{
${ }^{21}$ An excellent discussion of this for Norwich is given in Pelling, Common Lot. See also: Barlow, Gloucester, xxxi; Merson and Willis, Southampton, xvv-xvi, lxxiv.
} 
History 15, no. 4 (1985), 686). We calculate the numbers of apprentices per inhabitant at various points between 1600 and 1800 for Boston, Bristol, Coventry, Gloucester, Ipswich, Kings Lynn, Leicester, Lincoln, Liverpool, London, Northampton, Oxford, Southampton and St Albans. For small towns, we find a median of 4.3 apprentices per thousand people and an interquartile range of 2.6-5.7. For large towns, the median is 6.3 (2.810.3) apprentices per thousand people. Cols 1-2 give the median and interquartile range once multiplied by the number of towns in each category. Columns $3 \& 4$ are based on 6-year samples of IR1 (for 1712-1717 and 1792-1797); part of the underlying data was kindly shared by Karine van der Beek. Urban populations are derived from de Vries and Langton. The additional category of small boroughs are incorporated towns with a population over 1,000 in 1832. Estimates of 16 year old males outside agriculture are derived from E. A. Wrigley et al., English Population History from Family Reconstitution, 1580-1837 (Cambridge University Press, 1997), 614-5, 134. For 1600 we assume $65 \%$ of the male population are employed in agriculture (Patrick Wallis, Justin Colson and David Chilosi, 'Structural Change and Economic Growth in the British Economy before the Industrial Revolution, 1500-1800', Journal of Economic History 78, no. 3 (2018), 862-903). For 1700 and 1800, we use Broadberry et al's figures of $46 \%$ and $36 \%$ of males in agriculture (Stephen Broadberry, Bruce M. S. Campbell and Bas van Leeuwen, 'When Did Britain Industrialise? The Sectoral Distribution of the Labour Force and Labour Productivity in Britain, 1381-1851', Explorations in Economic History 50 (2013), 24). Estimates of the share of non-agricultural workforce outside towns assume that all urban workers are nonagricultural, and define the urban population as the share living in towns over 5,000 given in Wrigley, 'Urban Growth', 688.

Apprenticeship's large scale and enduring popularity is most evident when we compare the numbers who started indentures with the number of teenage males - the population from which they were primarily drawn. In 1600 and 1700, around one in ten teenage males started apprenticeships in a city or town. In the 1790 s, eight percent of teenage males started fee-paying apprenticeships, compared to eleven percent at the start of the century.

There is little sign here of sharp cycles in the popularity of apprenticeship over these two centuries. Although historians have long debated the 'decline' of apprenticeship in England, table 9.2 suggests that apprenticeship remained vigorous through the eighteenth century. ${ }^{22}$ It is only in the guilds that apprentice registrations declined steeply, as the ability and interest - of many guilds in enforcing local limits on economic activity weakened. ${ }^{23}$

Private apprenticeship did not retreat quickly in parallel with the guilds. There was some erosion in its significance: as employment outside agriculture rose in the eighteenth century, premium-paying apprentices fell from twenty to thirteen percent of all youths working in manufacturing or services between the 1710s and 1790s. But this may overstate developments, as industrialization meant that some of the new jobs were in low and semiskilled tasks where apprenticeship had limited relevance.

Individual trades and towns had specific histories that were more varied than this national average suggests. In some trades, loud complaints about unapprenticed workers emerged in the eighteenth century. Calico printers, shearmen and stocking weavers fought for jobs and wages by strengthening or re-establishing apprenticeship. ${ }^{24}$ In others, journeymen accused masters of recruiting excessive numbers of apprentices as cheap labour. In

\footnotetext{
22 The debate is well surveyed in Snell, Annals. Later major contributions include L. Schwarz, London in the Age of Industrialisation: Entrepreneurs, Labour Force and Living Conditions, 1700-1850 (Cambridge: Cambridge University Press, 1992); Humphries, Childhood and Child Labour.

${ }^{23}$ The many and growing gaps in guild and urban regulation are charted in Dunlop and Denman, English Apprenticeship; Stella Kramer, The English Craft Guilds: Studies in Their Progress and Decline (New York: Columbia University Press, 1927). See, however, M. Berlin, 'Guilds in decline? London Livery Companies and the rise of a liberal economy, 1600-1800', in: S.R. Epstein and M. Prak (eds.), Guilds, Innovation, and the European Economy, 1400-1800 (Cambridge: Cambridge University Press, 2008), 316-41.

${ }^{24}$ Rule, Experience, 1981.
} 
Spitalfields, rioting by silk weavers in 1719 was blamed on 'the covetousness of both masters and journeymen in taking so many 'prentices for the sake of the money they have with them; not considering whether they should have employment for them. ${ }^{25}$

It is uncertain how widespread such problems were, however. Few premodern trades were organised in a way that made apprentices central to production, in the way that child workers were to become in textile mills. And as guilds withdrew, journeymen often began campaigns to maintain apprenticeship via closed shops. ${ }^{26}$ Moreover, the estimates in table 2 are partial: the Stamp Tax just counted apprentices who pay premiums, and many did not. We thus cannot be sure if overall numbers are changing or just the share paying fees.

Nevertheless, the impression of persistence they provide coheres well with Jane Humphries' conclusion that apprenticeship remained commonplace for working-class youths into the early nineteenth century. ${ }^{27}$

London dominated urban apprenticeship in the seventeenth century. The great majority of England's urban apprentices were in London. The city's three to four thousand new apprentices a year around 1600 or 1700 was three to four times the number starting training in all England's other large towns combined. In the late seventeenth century, roughly one in ten of all English teenage males started an apprenticeship in London. This equates to one in five youths working outside agriculture. As Wrigley noted, London's disproportionate size and rapid growth depended on sucking in youths from across the nation. ${ }^{28}$ The impact on the city was particularly acute around 1600, when apprentices supplied around six to eight percent of the city's population (assuming a 60 percent survival rate); the social and political importance of apprentices in protest was rooted in this numerical heft. ${ }^{29}$

England's second and third tiers of cities played a much smaller part in apprenticeship. Where London faced a flood, these cities saw a trickle. In Lincoln population $c .4,000$ in 1700 - just 14 new apprentices a year were indentured in the midseventeenth century. In Gloucester, a county town with around 5,000 residents, around 40 to 50 apprentices were indentured each year in the seventeenth century. At least twice as many youths from Oxfordshire trained in London as in Oxford..$^{30}$ Even Bristol, the country's third largest city, received only 180 apprentices annually around 1600 and about 250 around 1700 , when its population reached about 24,000 people. Every year more apprentices were registered in London's larger guilds - the Merchant Taylors, Haberdashers, Weavers - than in Bristol. Still, Bristol was relatively important in training: its density of apprentices came close to that of London. Almost seven percent of Bristol's population were apprentices in 1600, and around four percent in 1700 (assuming 60 percent survived). In most towns, apprentices were one to two percent of the population. Apprentices were less important to

\footnotetext{
${ }^{25}$ The Weavers pretences examined (1719), quoted in ibid, 105

${ }^{26}$ Ibid, 111-12.

${ }^{27}$ Humphries, Childhood and Child Labour.

${ }^{28}$ E. A. Wrigley, 'A simple model of London's importance in changing English society and economy, 16501750', Past and Present 37 (1967), 44-70.

${ }^{29}$ Smith, 'Adolescents'; Tim Harris, London Crowds in the Reign of Charles II: Propaganda and Politics from the Restoration until the Exclusion Crisis (Cambridge: 1987).

${ }^{30}$ Counts of Oxfordshire apprentices in surviving London guild records exceed 100 per year on occasion in the seventeenth century; not all guild records survive.
} 
trade and manufacturing outside London, just as these towns were less important to apprenticeship.

Apprenticeship became less metropolitan, less urban and more geographically diffused in the eighteenth century. London remained the largest centre of training in Britain, but its exceptionality was reduced. In the 1710 s, 39 percent of apprentices paying premiums in England were indentured to London masters. By the 1790s, this had fallen to just 18 percent. To put this another way, in the 1710s, London received almost four times the number of apprentices that its share of England's population (11 percent) would predict; in the 1790s, it attracted roughly twice the share its population share (10 percent) suggested.

Figure 9.1. Maps of the distribution of apprenticeships with premiums in England and Wales, c. 1710 and c. 1790

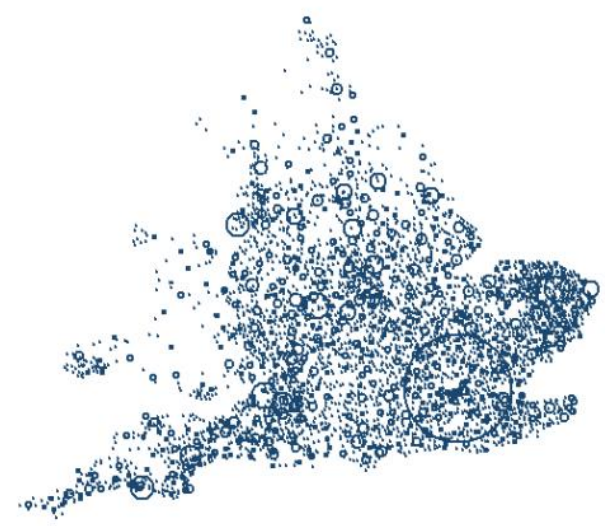

Note: The maps plot apprenticeships with premiums in the 1710s and 1790s where masters are in identifiable locations. Locations are represented by circles weighted by apprentice numbers. For 1710, a six year sample contained 30,542 indentures; $85.2 \%$ were successfully geo-located. For 1790 , the six year sample contained 36,102 indentures; $84.6 \%$ were successfully geo-located. Sources: IR1. 
Outside London, apprenticeships were distributed widely by the late eighteenth century, as map 1 shows. ${ }^{31}$ Masters in small centres - hamlets, villages, old market centres and new manufacturing towns - were recruiting premium-paying apprentices to a degree not found previously. The rest of England's established towns and cities (those with a population of 5,000 by 1800) took a constant fifth of apprentices. Some of this diffusion of training reflected the transformative effect of industry. In Lancashire, for example, the small hamlet of Hardshaw-within-Windle saw eleven apprentices in the 1790s, up from none in the 1710s, as it was drawn into the manufacturing and coal-mining town of St Helens (whose population would exceed 5,000 in the 1830s). ${ }^{32}$ The growth of clock-making in the area is apparent from their master's trades: four joined masters who made watches or watch-parts; the rest were bound to a surgeon, a draper, a carpenter, a cooper, a saddler and a joiner. Half paid less than $£ 10$, and just two paid more than $£ 20$ - those bound to the surgeon and the joiner. Similarly, Rainhill, a small township in the same county, saw three apprentices in the 1790s, against none in the 1710s. ${ }^{33}$ Two made watch parts and one became a saddler.

Yet much of England remained largely untouched by industrialization in this period, and apprenticeship was increasingly concentrated in these duller backwaters. In Bedfordshire, it was small hamlets such as Old Warden, where the local carpenter Thomas Preston bound a youth for $£ 6$, or Ridgmont, where two cordwainers and a wheelwright each took an apprentice (for $£ 5, £ 10$ and $£ 18$ respectively) that saw apprentices bound for premiums in the 1790 s, yet had seen none in the 1710s.

By the 1790s, it was the largely agricultural counties of Norfolk and Leicestershire that had the highest rates of apprenticeship per person, with 1.26 and 1.09 fee-paying apprentices per thousand inhabitants. Industrial Lancashire ranked thirty-fifth out of forty-one English counties with just 0.29 apprentices per thousand. ${ }^{34}$ In the Lancashire cotton industry or the woollen manufacturing of the West Riding of Yorkshire, formal indentures in trades such as weaving were rare in the late eighteenth century; that said, these were areas where proto-industry had long relied heavily on training within the family. ${ }^{35}$ The five cities with the highest concentrations of apprentices in the 1790s were Exeter, King's Lynn, Cambridge, Ipswich, and Norwich. These were not the heartland of industrialization; they were slowgrowing, relatively peripheral places in the East or South where traditional forms of employment and business organisation still predominated. Many of the trades youths entered were occupations servicing commercial agriculture: saddlers, blacksmiths, corn dealers and so on.

Because the Stamp Tax only applied to premium-paying apprentices, it is possible that the diffusion of apprenticeship that we see in table 1 and map 1 reflects changes in the

\footnotetext{
${ }^{31}$ Inevitably, not all locations of masters can be matched to identifiable places. However, the share matched (so far) is the same at $85 \%$ of English apprentices for the 1710s and 1790s. We expect this to rise as detailed matching of non-urban places has only been completed for a small sample of counties.

${ }^{32}$ In this paragraph, the 1710s and 1790s are six year samples for 1712-1717 and 1792-1797, respectively.

33 'Radnage - Raithby', in A Topographical Dictionary of England, ed. Samuel Lewis (London, 1848), 630-

33. British History Online http://www.british-history.ac.uk/topographical-dict/england/pp630-633 [accessed 14 May 2016].

${ }^{34}$ Our data does not distinguish the ridings of Yorkshire.

35 Derry, 'Enforcement'; Duncan Bythell, The Handloom Weavers: A Study in the English Cotton Industry

During the Industrial Revolution (Cambridge University Press, 1969), 36-38, 52-53.
} 
use of premiums, not apprenticeship itself. Perhaps village boys had been bound as often in the 1710s, but without fees? We cannot easily reject this hypothesis without evidence, that has not yet been found, on the frequency of rural apprenticeships without premiums.

However, there is little sign that apprentices were paying higher premiums, which we might also expect if demand was outstripping supply, and fee-paying apprenticeship was gradually becoming less common overall. ${ }^{36}$

This expansion in rural apprenticeship was part of a wider rebalancing of apprenticeship in this period. The diminishing importance of London as a source of training implies that more apprenticeships happened elsewhere. Many youths who trained in London would later return home - a quarter of provincial apprentices reappear in their parish of birth's vital records, either marrying, baptising a child or being buried. ${ }^{37}$ If fewer youths were making that initial journey, while the numbers working in industry and services was growing, then we would expect more youths to be training in the provinces, as we observe.

One consequence of this shift from London to the provinces was a reversal in the flow of skilled workers. Where skill had once spread outwards from London, as youths apprenticed in the city then migrated, by the mid-nineteenth century the metropolis was stocked with workers who had trained in small towns. In construction, for example, Mayhew suggested that in the 1850s three-quarters of carpenters were 'from the country', having moved to London as journeymen. ${ }^{38}$ The decline of guild powers encouraged this. English guild rules had favoured training within the guild; entry for people trained elsewhere was often prohibitively expensive. Now, provincial journeymen became acceptable.

We can see in outline a slow change in other aspects of apprenticeship. Over the seventeenth and eighteenth century, apprentices in London became younger - the age they started fell from nearly 18 years old around 1600 to 15.5 by $1800 .{ }^{39}$ (Apprenticeship always came after the age at which children received elementary education in literacy and numeracy). Terms also became shorter and less varied. Agreements beyond seven years became rare, although they had been relatively common in the sixteenth century. ${ }^{40}$ In some trades, by the late eighteenth century, even shorter apprenticeships started to appear -although mainly outside corporate towns. ${ }^{41}$ There is a sense in which apprenticeship became more predictable.

One final caveat needs to be stated about the balance of urban and rural apprenticeship. Until the Stamp Tax (and the introduction of settlement examinations, which occurred around the same time) we are almost entirely ignorant of apprenticeships outside

\footnotetext{
${ }^{36}$ Judicial decisions had also removed the requirement for a seven-year apprenticeship to trade in a country village in the mid eighteenth century (1 Ventr. 51; 2 Keb. 583).

${ }^{37}$ M. Klemp et al., 'Picking winners? The effect of birth order and migration on parental human capital investments in pre-modern England', European Review of Economic History 17 (2013), 224.

${ }^{38}$ Mayhew, in E.P. Thompson and M. Yeo (eds.), The Unknown Mayhew (London: Merlin Press1971), letter LX, 335 .

${ }^{39} \mathrm{P}$. Wallis, C. Webb and C. Minns, 'Leaving home and entering service: The age of apprenticeship in early modern London', Continuity and Change 25 (2010), 377-404. Even older ages are reported in the 1550s: S. Rappaport, Worlds within Worlds: Structures of Life in Sixteenth-Century London (Cambridge: Cambridge University Press, 1989), 295.

${ }^{40}$ For examples from Norwich, Southampton, see: Pelling, Common Lot, 214; Merson and Willis, Southampton, xix.

${ }^{41}$ Snell, Annals. 
corporate towns. Yet these were surely always the great majority of apprenticeships. ${ }^{42}$ Small towns, villages and the countryside were where the great majority of manufacturing and service work occurred. Without guilds, however, the evidence is scanty. Quarter sessions records, settlement examinations, and diaries and memoirs all suggest that rural apprenticeship was largely consistent with urban norms, but we still know too little about the subject. $^{43}$

Apprenticeship appears ubiquitous taken in the aggregate. Yet the distribution of apprentices across urban households and workshops was highly uneven. Romantic images of the artisanal household with master, wife, journeymen and apprentice as stock characters are deceptive. Many, perhaps most, guild members in London never took apprentices. ${ }^{44}$ Forty percent of the city's freemen apothecaries took no apprentices, for example. ${ }^{45}$ Those masters who did take apprentices often had just one or two over their lifetimes. Only a small minority of masters trained multiple apprentices over long careers. As Pelling showed for Norwich, these large employers often pushed up against guild limits on apprentice numbers. ${ }^{46}$

Most apprentices were bound to one of the rare masters who taught large numbers. In London, sixty percent of apprentices joined masters who taught five or more apprentices. Some masters would bind more than twenty over their careers, although they rarely had more than one or two at a time. These large masters charged higher premiums over time, as their experience and reputation grew; training became part of their business. ${ }^{47}$ It was also this group who attracted the ire of the smaller masters and journeymen, for taking too large a share of the trade or preferring cheap apprentices to waged journeymen. Most apprentices would not replicate the success of their master. In Gloucester, for example, only 15 percent of apprentice shoemakers or weavers would later take apprentices themselves. ${ }^{48}$ Training was concentrated, rather than distributed. Only a minority of masters had the volume of work, capacity, reputation and interest to attract numerous apprentices.

\section{Who was apprenticed?}

One crucial issue for our understanding of early modern apprenticeship is how accessible it was to different people. If access to training was restricted to a specific group, whether by formal rules or informal norms, then it would be socially unjust and economically pernicious. Given that the right to skilled work was tied to completion, apprenticeship would be another institution generating rents for insiders. ${ }^{49}$

\footnotetext{
${ }^{42}$ Pelling, Common Lot, 119-20.

43 The fullest discussion remains: Snell, Annals.

${ }^{44}$ Exact estimates are complicated by the difficulty of matching by name across registers. Estimates from a sample of 8 London guilds, suggest at least 40 to 50 percent of freemen did not take apprentices.

${ }^{45}$ Patrick Wallis, 'Medicines for London: The Trade, Regulation and Lifecycle of London Apothecaries, C. 1610-C.1670' (D.Phil, University of Oxford, 2002), 170.

${ }^{46}$ Pelling, Common Lot, 216-19

${ }^{47}$ Minns and Wallis, 'Price of human capital', 348-49.

${ }^{48}$ Barlow, Gloucester: xx.

${ }^{49}$ For the fullest discussion of this, see S. Ogilvie, 'Guilds, efficiency, and social capital: Evidence from German proto-industry', Economic History Review 57 (2004), 286-333, Sheilagh Ogilvie, 'How does social capital affect women? Guilds and communities in early modern Germany', American Historical Review 109 (2004), 325-59; Sheilagh Ogilvie, "'Whatever is, is right”? Economic institutions in pre-industrial Europe,' Economic History Review 60 (2007), 649-84.
} 
At the simplest level, this charge does not appear to hold for apprenticeship in early modern England. Apprenticeship encompassed the children of rich and poor, townsmen and country folk, farmers and merchants. It was an open institution. To a large extent, recruitment on the scale just described necessitated this. Statutory restrictions on who could enter urban crafts seem to have had little effect - and there is little evidence of attempts to enforce them at law. ${ }^{50}$ Nor did guilds impose tight social restrictions on entry.

Still, the opportunity to enter an apprenticeship was not evenly spread across society. Apprenticeship came with costs: it removed a pair of productive hands from a household at the age they finally became valuable. It took time and money to arrange: youths needed a stock of clothing at the very least. These direct financial barriers were probably more important than Statute, guild rules or exclusive artisanal norms in defining the prospects of children. Premiums, particularly, were a source of inequality. Fees were lower than has sometimes been thought. As we saw (Table 1), median premiums were five to ten pounds in most trades. Nonetheless, with unskilled provincial wages hovering around twelve pounds a year, these were difficult sums for poorer families, even with the chance of assistance from parish or charity. One inevitable effect was that poorer children largely ended up in the least prosperous trades. ${ }^{51}$ The rich - and well-connected urban children whose might escape paying - had an important advantage in the labour market.

Because city and guild registers record the occupations of apprentices' fathers, we can examine the degree of inequality in urban apprenticeship (Table 3). Poverty had a substantial impact. The low share of apprentices whose fathers were described as labourers suggests that movement into (non-pauper) apprenticeship was relatively rare for these families. Labourer might be an under-used label, given that apprentices had some control over the wording of indentures, but a great gulf existed between these figures and the numbers of labourers in the population. In 1688, King put 43 percent of the population into his class of 'labourers, cottagers and paupers'; more recent estimates are lower,

\footnotetext{
${ }^{50}$ Derry, 'Enforcement', 3-6.

${ }^{51}$ Charity funding for apprenticeship was increasingly abundant and important from the early $17^{\text {th }}$ century onwards.
} 
Table 9.3. Backgrounds of Apprentices in English towns and cities, $17^{\text {th }}-18^{\text {th }}$ centuries

\begin{tabular}{|c|c|c|c|c|c|c|c|}
\hline & $\begin{array}{l}\text { London } \\
1600-25\end{array}$ & $\begin{array}{l}\text { Gloucester } \\
1600-25\end{array}$ & $\begin{array}{l}\text { Boston } \\
1650-75\end{array}$ & $\begin{array}{l}\text { Lincoln } \\
1650-75\end{array}$ & $\begin{array}{l}\text { Leicester } \\
1646-48\end{array}$ & & \\
\hline \multicolumn{8}{|c|}{ A. Parental occupation/status } \\
\hline Gentleman (\%) & 13.9 & 6.5 & 9.9 & 9.7 & 0.9 & & \\
\hline Yeoman $(\%)$ & 34.7 & 26.8 & 12.1 & 19.4 & 10.4 & & \\
\hline Husbandman (\%) & 7.7 & 18.8 & 7.7 & 8.1 & 16.5 & & \\
\hline Labourer $(\%)$ & 0.7 & 3.7 & 9.9 & 17.7 & 10.4 & & \\
\hline \multicolumn{8}{|l|}{ Parental Sector } \\
\hline Agriculture (\%) & 54.5 & 52.4 & 30 & 41.9 & 31.6 & & \\
\hline Manufacturing (\%) & 29.2 & 37.3 & 48.6 & 46.5 & 55.1 & & \\
\hline \multirow[t]{2}{*}{ Services $(\%)$} & 16.3 & 10.3 & 21.4 & 11.6 & 13.3 & & \\
\hline & 100 & 100 & 100 & 100 & 100 & & \\
\hline \multicolumn{8}{|l|}{ B. Ties } \\
\hline Local origin $(\%)$ & 14.7 & 27.2 & & 44.4 & 45.7 & & \\
\hline Same occupn. (\%) & & 10.9 & 10.6 & 26.9 & 16.8 & & \\
\hline \multicolumn{8}{|l|}{ Father is master } \\
\hline \multicolumn{7}{|l|}{ Father deceased } & \\
\hline $\mathrm{N}$ & 37,457 & 616 & 91 & 62 & 115 & & \\
\hline \multirow[t]{2}{*}{$\mathrm{N}$ guilds } & 58 & & & & & & \\
\hline & $\begin{array}{l}\text { London } \\
1700-25 \\
\end{array}$ & $\begin{array}{l}\text { Gloucester } \\
1700-25 \\
\end{array}$ & $\begin{array}{l}\text { Boston } \\
1700-25 \\
\end{array}$ & $\begin{array}{l}\text { Lincoln } \\
1750-75 \\
\end{array}$ & $\begin{array}{l}\text { Bristol } \\
\text { c. } 1690 \\
\end{array}$ & $\begin{array}{l}\text { Liverpool } \\
1700-25 \\
\end{array}$ & $\begin{array}{l}\text { Shrewsbury } \\
\text { c. } 1690\end{array}$ \\
\hline \multicolumn{8}{|c|}{ A. Parental occupation/status } \\
\hline Gentleman $(\%)$ & 9.1 & 4.8 & 3.2 & 3.4 & 8.3 & 16.4 & 22.4 \\
\hline Yeoman $(\%)$ & 8.1 & 21.8 & 6.3 & 3.4 & 12.8 & 14.5 & 5.6 \\
\hline Husbandman (\%) & 4 & 0 & 0 & 1.5 & 0.3 & 17.8 & 2.4 \\
\hline Labourer (\%) & 4.2 & 5.8 & 10.5 & 13.1 & 2.2 & 0.8 & 0.8 \\
\hline \multicolumn{8}{|l|}{ Parental Sector } \\
\hline Agriculture (\%) & 19 & 27.6 & 23.9 & 33.5 & 22.7 & 42.2 & 10.4 \\
\hline Manufacturing (\%) & 51.2 & 58.5 & 47.8 & 46.2 & 51.1 & 29.6 & 68.8 \\
\hline \multirow[t]{2}{*}{ Services $(\%)$} & 29.7 & 13.9 & 28.4 & 20.4 & 26.2 & 28.2 & 20.8 \\
\hline & 100 & 100 & 100 & 100 & 100 & 100 & 100 \\
\hline \multicolumn{8}{|l|}{ B. Ties } \\
\hline Local origin $(\%)$ & 47.1 & 52.4 & 2.7 & 38.9 & 45.3 & 10.3 & 38.6 \\
\hline Same occupn. (\%) & 11.1 & 20.5 & 6.3 & 18 & 19.2 & 4.7 & 25.6 \\
\hline $\begin{array}{l}\text { Father is master } \\
(\%)\end{array}$ & 2.9 & 0 & 11.7 & 0 & 9.7 & 1 & 15.4 \\
\hline $\begin{array}{l}\text { Father deceased } \\
(\%)\end{array}$ & 22.4 & & 4.9 & 16 & & 21.4 & 13.6 \\
\hline $\mathrm{N}$ & 48,669 & 1037 & 95 & 268 & 2,135 & 366 & 125 \\
\hline $\mathrm{N}$ guilds & 67 & & & & & & 5 \\
\hline
\end{tabular}


Note: Panel A reports the reported occupation/status of apprentices' fathers, expressed as a share of all apprentices with relevant information. Rows 5-7 follow Wrigley's Primary, Secondary, Tertiary classification. Panel B reports the share of apprentices with ties, as defined in T. Leunig, C. Minns and P. Wallis, 'Networks in the pre-modern economy: The market for London apprenticeships, 1600-1749', Journal of Economic History 71 (2011), 413-43. Sources: London: C. Webb, London Apprentices 44 vols. (London: Society of Genealogists, 1996-2007), London Livery Companies Online (rollco.org), and Scott (Merchant Taylors); Bristol: Bristol Record Office, 04353/2; Gloucester: Barlow, Gloucester; Boston and Lincoln were kindly supplied by the Lincoln Family History Society; Leicester: H. Hartopp (ed.), Register of the Freemen of Leicester, 1196-1770 (Corporation of the City of Leicester, 1927); Liverpool: M. Power, F. Lewis, and D. Ascott, Liverpool Community, 1649-1750, SN: 3882 (Colchester, Essex: UK Data Archive, 1998); Shrewsbury: Shropshire Archives MS6001/126 (Glovers); 6001/4263 (Mercers); $6001 / 5837$ (Tailors); 6001/3360 (Weavers); 6001/4583 (Smiths).

yet still far in excess of the 4 percent of apprentices paying premiums in the early eighteenth century who were identified as labourers' children. ${ }^{52}$ In London, between 1500 and 1799, only 2 percent of apprentices were sons of labourers. Higher shares are sometimes observed. In 1650-74, 18 percent of Lincoln apprentices were labourers' sons. But Gloucester, Liverpool, Bristol, Boston were all similar to London. These are private apprenticeships; the share of labourers' children among pauper apprentices was presumably much higher.

At the other end of the social distribution, sons of gentlemen were relatively numerous: 13 percent of apprentices across these samples, compared to the 1.4 percent of the population King estimated. London attracted many - more than 30,000 gentry sons in the seventeenth century alone - but so did Liverpool, with its prosperous merchant houses. Even smaller cities saw substantial numbers. Many merchants and wholesalers came from gentry families. The degree of gentility of these fathers has long been debated. Were they merely socially-aspirational large farmers - 'parish gentry', in Brooks' words? Some probably were, but a considerable number can be traced in contemporary lists of armigerous gentlemen. ${ }^{53}$ These people had asserted a credible claim to gentility before the officials responsible for defining the status; they include Members of Parliament and Justices of the Peace. The Surrey gentleman Arthur Onslow's eldest son, Richard, became Chancellor of the Exchequer in 1715; his fourth son, Henry, had been apprenticed in the Grocers' Company in 1683.

Wealth aside, some other potential biases had little effect. There was little preference for local children. Instead, apprenticeship was tightly entangled with migration. Roughly speaking, the distance that apprentices travelled varied inversely to a town's population. London's apprentices, in particular, had often journeyed long distances. This was in part a demographic necessity: the metropolis only supplied 15 percent of its own apprentices in the early seventeenth century when it was growing most rapidly. Smaller cities, too, depended on apprentice migration. Around 1600, in Southampton and Gloucester, just a third apprentices were locals.

Nor did masters limit entry to the sons of those already in the trade. Many apprentices came from a background in agriculture, not manufacturing or services. In the first quarter of

\footnotetext{
${ }^{52}$ Broadberry, 'When did', 19; Minns and Wallis, 'Price of human capital', 9.

${ }^{53} \mathrm{P}$. Wallis and C. Webb, 'The education and training of gentry sons in early modern England', Social History 36 (2011), 36-53.
} 
the seventeenth century, 55 percent of London apprentices and 52 percent of Gloucester apprentices were from farming backgrounds, compared to perhaps 60 to 65 percent of the population. ${ }^{54}$ A century later, 19 percent of London apprentices, 28 percent of Gloucester and 25 percent of Boston apprentices were from farming families. By that stage, agriculture employed around 40 percent of adult males. Both migrants and youths changing trade tended to pay higher premiums; mobility had its price, probably because of the greater risk of contracts failing early. ${ }^{55}$ Yet apprenticeship was, and remained, a well-travelled road between sectors and occupations.

The largest 'missing' group among apprentices were women. This was not because of formal restrictions. Female apprentices were rarely banned in England. Only one London guild, the Weavers', is known to have proscribed training 'any mayde damsel or other woeman whatsoever'. Women could become freemen of London and many other cities via apprenticeship. ${ }^{56}$ But expectations about gender roles and marriage (the husband's freedom or citizenship superseded his wife's rights, at least in London) lowered the incentive to invest in girls' human capital. Girls placed in pauper apprenticeships usually learned 'housewifery'. Many must have learned trades from their parents. Private apprenticeships of women were rare, however.

In London, roughly one percent of apprentices registered by guilds were female, as were perhaps five percent of apprentices paying premiums in the eighteenth century. ${ }^{57}$ Guild records probably underestimate training; as Amy Erickson has suggested, female apprentices were more likely to be bound for shorter terms, as meeting the Statutory requirement was less important to them, and so might not be registered. ${ }^{58}$ Nonetheless, there can be no doubt that women were far less frequently apprenticed than men. Female apprentices often joined a small number of trades, particularly millinery or another clothing trades, although examples occur in most occupations. ${ }^{59}$ In some cases, parents did invest substantial sums; Erickson has tracked a cluster of respectable families apprenticing their daughters to milliners in the $1700 \mathrm{~s}$ with premiums of $£ 30$ to $£ 60 .{ }^{60}$ Unusually, their contracts named both husband and wife as master, suggesting that it was the mistress who would train them.

Most apprentices were entering different occupations to their father. But for children born into craft or trade families, apprenticeship was less obviously a mechanism for occupational mobility. The most obvious examples are those youths who were bound to their fathers. In London, master's sons supplied just 2 percent of apprentices, but they made up 15 percent in Shrewsbury in the 1690s and in Leicester in the 1650s. That sons entered contracts with their fathers highlights one tension between the Statute of Artificers, which did not recognise any form of skill inheritance for artisans' sons, and that of cities and guilds, which

\footnotetext{
54 To ensure comparability, these figures compare the share of apprentices with fathers identifiable as in agriculture, industry or services to estimates for the male population. Gentry etc are excluded. See Wallis, Colson and Chilosi, 'Structural change'.

55 Minns and Wallis, 'Price of human capital'.

${ }^{56}$ Ordinances, Guildhall Library, MS 4647, \#12

${ }^{57}$ A.L. Erickson, 'Eleanor Mosley and other milliners in the City of London Companies 1700-1750,' History Workshop Journal 71 (2011), 150

58 A.L. Erickson, Women and Property in Early Modern England (London: Routledge, 1993), 55.

${ }^{59}$ Snell, Annals.

${ }^{60}$ Erickson, 'Eleanor Mosley'.
} 
frequently gave masters' sons the right to claim membership by inheritance. ${ }^{61}$ By formalising within-family training as an apprenticeship, fathers made the years their sons spent working with them transferrable, should they die or fail in trade, and legally meaningful.

Christopher Brooks has argued that the openness of apprenticeship declined in the late seventeenth and eighteenth centuries. ${ }^{62}$ This pathway into the urban community narrowed and contributed to the rise of urban oligarchies. Signs of this can be found in the narrowing of migration fields over the seventeenth century. By 1700, for example, Gloucester supplied more than half of its own apprentices; just 6 percent now travelled more than 25 miles. Similarly, London now gathered almost half of its apprentices from Middlesex. Migrant apprentices were much more likely to come from the south east, although some did still travel further. The share of freemen entering by patrimony also rose.

On the other hand, there is no evidence that these developments resulted from deliberate decisions by cities or guilds. The freedom of some London guilds did become a more costly proposition, but apprenticeship outside guilds was sustained, and premiums did not rise in real terms, as we would expect if guilds were raising barriers. Increasingly local recruitment may simply reflect the growth of manufacturing outside the old cities, and the slowing of London's breakneck rate of expansion. Better provincial opportunities meant that prospective apprentices no longer needed to travel. Elsewhere in Europe, youths tended to train near their families, allowing parents to support their children, and one imagines that English parents would have favoured this too. Conversely, London was now able to supply more of its own apprentices, and it was increasingly accessible to skilled adult migrants. ${ }^{63}$ To see this as period as marked by the closing off of the city to outsiders seems an exaggeration, in short.

\section{Apprenticeship and Family Structure}

The point, and the desirability, of apprenticeship varied between families, depending on their occupation, wealth, local inheritance system, and family size. The choices families made about which child to apprentice illustrate this clearly. In gentry families, apprentices were usually younger sons; few eldest sons were apprenticed, as one would expect in a situation in which landed wealth (and status) was transferred through primogeniture. Instead they studied law or spent time at a university. The odds of apprenticeship increased with each step down the birth order, as figure 1 shows.

Farming families, headed by yeomen or husbandmen, echoed the gentry's habit of mainly apprenticing younger sons, suggesting that for elder sons inheriting the farm trumped migration into town. ${ }^{64}$ Conversely, urban inheritance was often partible and urban resources and

Figure 9.2. The effect of Birth Order on Education and Training among gentry

\footnotetext{
${ }^{61}$ Legal developments in the eighteenth century arguably changed this by recognising time spent working, even without an indenture.

${ }^{62}$ Brooks, 'Apprenticeship'.

${ }^{63}$ This may also reflect improving changes of survival for urban children.

${ }^{64}$ Klemp et al., 'Picking winners'. 


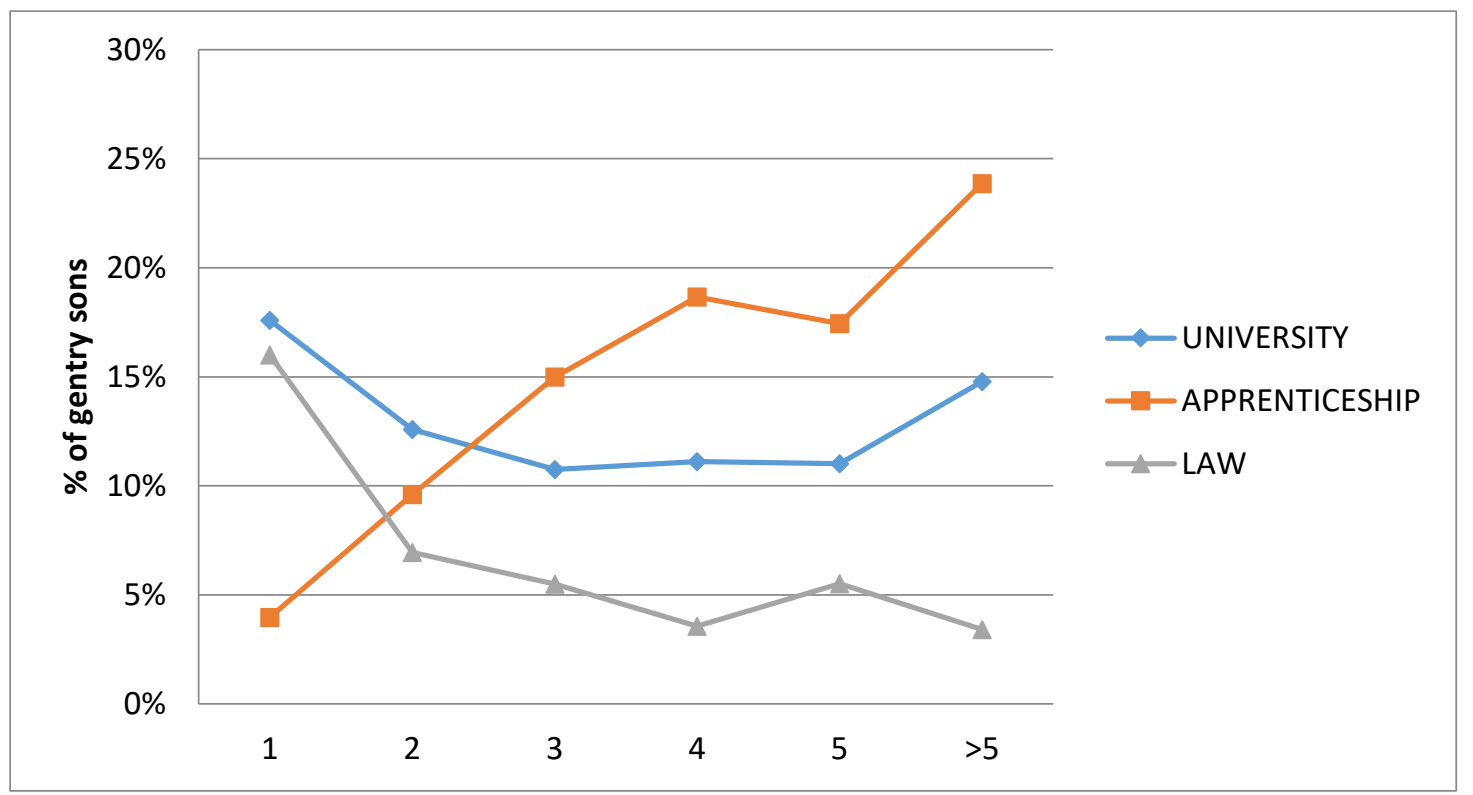

Source: Wallis and Webb, 'Education and training', 49. The figure reports the destination of sons in a sample of gentry families, by birth order.

networks were already tied to crafts and trade. Hence, for children of the urban middling sort birth order mattered little. In poor families rural norms were reversed: labourers' eldest sons were more likely to be apprenticed, as opportunities were directed towards eldest sons.

Yet individual interest mattered too. That urban families placed children into apprenticeships largely independent of birth position suggests that their ability and enthusiasm played a part in defining who followed what pathway. Certainly, Robert Campbell's advice to parents emphasised the importance of matching the 'Genius and Temper' of children to their career. ${ }^{65}$ Ben-Amos has shown how youths usually had a voice in choosing their career. Apprenticeships usually started with a month-long trial period to accommodate this. Adam Martindale (b.1623), for one, returned to school to prepare for university after a few weeks as an apprentice, his father seeing 'which way my mind still went'. ${ }^{66}$

Family breakdown could also push a youth into an apprenticeship, but this was not its usual prompt. High rates of adult mortality meant that teenagers frequently lost one or both parents. Apprenticeship offered one way to manage the impact of death on the household. In the small port of Rye, Mayhew found that formal apprenticeship was primarily a way to settle orphans and migrants into stable homes. ${ }^{67}$ But apprenticeship was too extensive - and too expensive - to be primarily a mechanism for crisis resolution, and only a minority of children would be orphaned at the right age for apprenticeship to help. In London, Boston, Liverpool, Shrewsbury and Leicester, around a quarter of apprentices had lost their father. These are roughly the levels we would expect from adult mortality rates. Only Boston mirrored Rye: 75

\footnotetext{
${ }^{65}$ R. Campbell, The London Tradesman (London: T. Gardner, 1747), 17.

${ }^{66}$ Adam Martindale, Diary, in: J. J. Bagley, (ed.), Lancashire Diarists: Three Centuries of Lancashire Lives (London: Phillimore, 1975).

${ }^{67}$ The Unknown Mayhew; see also Pelling 'Apprenticeship', and Pelling, Common Lot.
} 
percent of local apprentices had deceased fathers, compared to 28 percent of migrants. Elsewhere, the difference was small.

Ideally, we would now look at who did not become apprentices. How many artisan families trained their sons at home, perhaps lining them up to take over their workshop? How strictly did families stick to the north-west European norm of transferring adolescents to another household? Direct evidence is hard to obtain. Those sons who were not indentured are, generally, almost invisible. One partial indicator is the share of guild members who entered by inheritance, or 'patrimony'. That freemen by patrimony were usually a small share of members suggests that most urban families did place children into apprenticeships. In Liverpool in the second half of the seventeenth century, only 11 percent became freemen by inheritance, in London 20 to 30 percent of freemen entered the Clothworkers, Merchant Taylors and Apothecaries guilds by inheritance. Unfortunately, these figures give a clearer indication of the openness of guilds and cities -ex-apprentices made up the vast majority of new freemen and citizens - than of the degree to which families trained their own.

The large scale of apprenticeship migration in England had one further effect: it overwhelmed any reliance on chains of family ties or regional clusters to guide relationships. ${ }^{68}$ London, particularly, recruited in such large numbers that most apprentices had no direct connection with their a master. The concentration of training with a minority of masters further limited the chance of joining someone known to the family. Masters were themselves likely to have migrated to London, but they usually came from a different place and county to their apprentices. Most apprentices' fathers - 80 to 90 percent - were in different trades or sectors, removing the possibility of occupational ties. No doubt apprentices exploited kin ties where they existed, but most - 92 percent in London -joined masters with no obvious family link, judged by surname. Even in smaller cities, apprentices generally trained outside their families: apprentices and masters with different surnames account for 95 percent of apprentices in Liverpool, 97 percent in Leicester, 85 percent in Bristol, 83 percent in Boston, 95 percent in Lincoln, 87 percent in Gloucester and 79 percent in Shrewsbury. ${ }^{69}$ Kin ties increased as apprentices increasingly came from the area. But they were never the norm.

Contracts made with masters outside families' immediate networks often relied on intermediaries to bridge the gap. To give one example, George Bewley, travelled from Cumberland to bind himself to Edward Webb, a Dublin linen draper, after a travelling Quaker minister, Gershon Boat, 'proposed to my parents their sending me to Dublin, in which City he thought he could readily provide me a Place'. Boat was true to his word, and soon after his return Webb wrote to Bewley's parents asking for George to be sent over. ${ }^{70}$

Apprenticeship in England was a mechanism to shift out of the family trade, not reinforce it. It was a way to leave places, not stay in them. It was a solvent, in an already fluid society. We know that families took pains to identify good masters, and exploited connections to find opportunities, but the second or third degree ties they might have to masters via intermediaries such as Boat were weak, certainly too weak carry much weight in

\footnotetext{
${ }^{68}$ Leunig, Minns, Wallis, 'Networks'. Earlier evidence is surveyed in Pelling, Common Lot, 122.

${ }^{69}$ These counts include apprentices training with reported kin, such as fathers. Rates excluding reported kin are much lower.

${ }^{70}$ G. Bewley, A Narrative of the Christian Experiences (Dublin, 1750), 10-11.
} 
avoiding abuse or disputes. As Mark Granovetter argued, weak ties are primarily important for information. These two fundamental aspects of English apprenticeship - the extent of migration and the scarcity of informal ties - are entangled with its institutional history and the approach to apprenticeship contract that developed.

\section{Institutions and the experience of service}

How apprentices learned their crafts, and their experiences of life in new, often distant households, have left few traces. The one point when they do sometimes come to light is when an apprenticeship broke down. This process of breakdown - and the role of institutions in preventing or resolving disputes, and more generally in enforcing contracts - has attracted scrutiny in recent years, provoked by S R Epstein's hypothesis that apprenticeship contractenforcement provided a positive role and justification for guilds. ${ }^{71}$ Apprenticeship operated with weakly specified contracts and time-inconsistent investments and payoffs. How might masters ensure that apprentices did not abscond once they were trained, or apprentices avoid being exploited as cheap labour by their masters? Did institutions intervene to help?

In England, at least, the question was ducked. Institutions made relatively few efforts to enforce apprenticeship contracts once the arrangement had been undermined. Enforcement was not impossible. The full force of the law was deployed against recalcitrant workers in the nineteenth century by magistrates and managers. They exploited the master-servant acts to prevent apprentices and other employees quitting. ${ }^{72}$ In the sixteenth to eighteenth centuries, however, institutions favoured allowing exit over enforcement.

Doing so acknowledged the basic fluidity of early-modern apprenticeship. The impermanence of apprenticeship contracts can be illustrated for London and Bristol in the 1690s, when listings of households allow us to observe the probability that apprentices were absence at different points in their terms ${ }^{73}$ Figure 2 shows how apprentices drifted in slowly, often months after the clock had started. After three or four years, many then left - having served periods similar to those set in contracts in France and the Southern Netherlands. Some apprentices left service entirely. Others simply moved to a different master; turnovers were recorded formally for around one in ten apprentices. ${ }^{74}$ Those who stayed after the midpoint generally made it to the end. But once their terms were over, they would rapidly leave.

[Figure 9.3 near here]

The spur for these premature departures varied. Apprentices might dislike the trade, squabble with their master, or be called home to support their family. Some fell in love; others into crime. One apprentice pewterer, John Walmesley, told his master's maid that 'he

\footnotetext{
${ }^{71}$ S.R. Epstein, 'Craft guilds, apprenticeship, and technological change in preindustrial Europe', Journal of Economic History 58 (1998), 684-713.

72 D. Hay and P. Craven, Masters, Servants, and Magistrates in Britain and the Empire, 1562-1955, Studies in Legal History (Chapel Hill: University of North Carolina Press, 2004).

${ }^{73}$ C. Minns and P. Wallis, 'Rules and reality: Quantifying the practice of apprenticeship in pre-modern England', Economic History Review 65 (2012), 556-79. See also P. Wallis, 'Apprenticeship and training in premodern England', Journal of Economic History 68 (2008), 832-61

${ }^{74}$ Minns and Wallis, 'Rules and reality'. See also Barlow, Gloucester.
} 
would not stay ... for that he had no mind to a handicraft trade' ${ }^{75}$ Masters might force out apprentices if they discovered a fault - or simply wanted to avoid the cost of keeping them. Masters' responsibilities included the potentially heavy burden of caring for apprentices who fell sick. ${ }^{76}$ Travelling or working in another household, even another country, to gain experience account for another group of apprentices, whose departures were temporary. An apprentice shipwright, Phineas Pett spent time away assisting two other master shipwrights. ${ }^{77}$ For merchants' apprentices, in particular, working as a factor abroad was often specified as part of the apprenticeship - a rare case of the content being detailed.

High rates of departure by apprentices - whether quits or transfers - affect the way in which training occurs under apprenticeship. ${ }^{78} \mathrm{~A}$ high risk of apprentices leaving will make masters reluctant to invest much in training. Masters instead will ensure that youths work enough to cover much of their costs as they go; unskilled tasks (sweeping, carrying, watching) allowed this. Premiums offer a different solution, off-setting masters' investment. But we would still expect that instruction would have been slower, with apprentices more often left to 'steal with their eyes', than in a situation in which contracts were better enforced.

Exit found its institutional apogee in the Lord Mayor's Court of London. ${ }^{79}$ At the epicentre of England's market for apprenticeship, sitting in the Guildhall of the City of London, notionally headed by the Mayor himself, the Lord Mayor's Court offered a rapid, affordable and accessible way for youths to abandon their indentures and, later, to recover part of their premium. By the later seventeenth century, over one in ten London apprentices used the Court. More apprentices were discharged there than existed in other English cities.

Its process was simple. The youth entered a complaint against their master under one of a range of categories (turning them out, insufficient food or training etc.), the master was summoned, and - when he failed to appear, as most did - the apprentice was released from their contract, and allowed to find a new master (without losing the time served) or depart entirely.

The Court's formal process concealed a messier reality. The most common plea was that a master had failed to enrol their apprentice's contract with the City Chamberlain within a year. Against this breach of city law (and their freeman's oath), no defence existed.

Subsequent law suits in which apprentices sought to recover their premiums contain much gorier tales of abuse, neglect and malfeasance on both sides. ${ }^{80}$ Masters who starved and beat their apprentices. Apprentices who lied and stole.

The dry formality of a non-enrolment plea concealed all sins. It also presented a paradox. For a master's failure to fulfil a simple bureaucratic exercise left them with no way to defend any investment in their apprentice. We might reasonably suspect that both sides frequently understood this, and that the right to an easy exit was anticipated in negotiations

\footnotetext{
${ }^{75}$ CLRO, MC6/526A.

${ }^{76}$ Pelling, Common Lot, 124-28.

${ }^{77}$ Ilana Krausman Ben-Amos, 'Service and the coming of age of young men in seventeenth-century England', Continuity and Change 3 (1988), 41-64.

${ }^{78}$ Wallis, 'Apprenticeship and training'.

${ }^{79}$ P. Wallis, 'Labor, law and training in early modern London: Apprenticeship and the City's institutions', Journal of British Studies 51 (2012), 791-819.

${ }^{80}$ These records are discussed in detail in Pelling, 'Apprenticeship'; Griffiths, Youth and Authority; Wallis,

'Labour, law and training'.
} 
over an apprenticeship. In effect, these apprenticeship contracts were deliberately unenforceable.

Outside London, no town appears to have operated a court with the same dedicated process as London. To be fair, none had the same concentration of apprentices. Nonetheless, strong echoes of the system appear elsewhere. Enrolment was patchy in most cities where this requirement occurred. ${ }^{81}$ Exit was instead managed by magistrates. As Blackstone recounted, 'Apprentices to trades may be discharged on reasonable cause, either at the request of themselves or masters, at the quarter sessions, or by one justice', followed by 'direct restitution of a rateable share of the money given with the apprentice. ${ }^{82}$ Discharges often concluded those disputes brought before Justices of the Peace; one West-Country broad weaver described how 'A difference in opinion arose, and I went to a Magistrate and he released me'. ${ }^{83}$ In Gloucester, by the later seventeenth century, youths were being recorded as discharged 'by order of the sessions'. ${ }^{84}$ London's distinctive formal system reflected the sheer scale of apprenticeship in the city; it may also have provided an additional incentive for families to concentrate on the metropolis.

That apprenticeship might be ended cleanly and legally did not preclude other disciplinary processes. ${ }^{85}$ Masters retained and exercised the right to physically punish apprentices - apprentices protested against excessive correction, not violence per se. As subordinates within households, apprentices faced the same patriarchal authority as other servants, and children and wives. In London, the city launched repeated campaigns to improve the morality and deference of apprentices, who were enjoined to cut their hair, dress modestly, stay indoors at night, and not hunt, play football or dance. ${ }^{86}$ Guilds too might discipline apprentices, although examples only occur rarely. In London, the city's Chamberlain heard complaints from masters and regularly prescribed whipping or periods of hard labour in the city's gaols.

The possibility of exit heightened inequalities between apprentices. The Lord Mayor's Court might have been cheap, but it was of most use to those who possessed sufficient familial resources and capital to survive the sacrifice of the time and money they had sunk into their first apprenticeship. Quitting early was costly; it could damage a youth's reputation. ${ }^{87}$ The distribution of the early departures we observe in London and Bristol illustrates this. ${ }^{88}$ Wealthy migrant apprentices were more likely to leave; migrant labourers' children were more likely to stay, as were youths with strong local connections. Apprentices who had better outside opportunities were more footloose than those with ties to the community. The price - and the opportunity cost - of exit was not equal for all. When the Essex clergyman Ralph Josselin's son John quit his apprenticeship in London, it was a

\footnotetext{
${ }^{81}$ Barlow, Gloucester, xiv. Enrolment was required in Southampton from the fifteenth century, but essentially disappeared by the late seventeenth; it was frequently delayed: Merson and Willis, Southampton, xii-xiii, xv.

${ }^{82}$ Blackstone, Commentaries, 414.

${ }^{83}$ Quoted in Rule, Experience, 98.

${ }^{84}$ Barlow, Gloucester, xx. See also Graham, Oxford, xxiii; Merson and Willis, Southampton, xx.

${ }^{85}$ P. Griffiths, Youth and Authority: Formative Experiences in England, 1560-1640 (Oxford: Clarendon Press, 1996).

${ }^{86}$ LMA, Rep. 554, f. 267v. These efforts are well surveyed in Smith, 'Adolescents'.

${ }^{87}$ Evidence on the cost of an early exit is elegantly presented in Humphries, Childhood.

${ }^{88}$ Minns and Wallis, 'Rules and reality'.
} 
disappointment to his father, who noted 'sadness in my family, John returned' in his diary. But John could return to his family home, his subsistence assured. ${ }^{89}$ One by-product of this was that masters demanded a higher premium from apprentices who were more likely to leave. ${ }^{90}$ Inequality was institutionalised in other ways in the eighteenth century, as Statute gave Justices of the Peace increasing powers of summary intervention into apprenticeships in which premiums were small or non-existent. Those who had spent substantial sums were only to be dealt with at the full Quarter Sessions.

Cities, magistrates and guilds had a much less clear role in the completion of an apprenticeship than they had in breaking contracts. No English guilds or cities are known to have monitored successful completions. There was no examination or certification waiting for apprentices. Those tests that did exist -fewer than half of London guilds required a 'masterpiece'- applied to individuals seeking guild membership. ${ }^{91}$ These were not portable proofs of ability and success. They carried no weight elsewhere, unlike the Lehrbrief issued by some Dutch and German guilds.

The link between apprenticeship and the testing of skills was vaguer even than this suggests. First, it is unclear how universally guilds employed examinations of new members even when the rule existed. In London, particularly, freemen often worked in - and trained apprentices - in trades that were not governed by their guild, rendering masterpieces moot. How, for instance, should the Coopers test a woollen draper? Secondly, despite guild rules that pressed apprentices to become freemen promptly, many waited for years, working as journeymen without entering the guild. In practice, few guilds were attentive enough to ensure that all journeymen were members - and some explicitly delayed any test until journeymen wished to set up as masters. ${ }^{92}$ As a result, most ex-apprentices would never take a mastership test.

Few apprentices would enter their masters' guild or become urban citizens. Rates varied, but in general only around 40 percent of apprentices became freemen. This was not because of guild barriers. Most imposed relatively low fees; in London, they were capped by law at $3 \mathrm{~s} 4 \mathrm{~d} .{ }^{93}$ Actual charges might be somewhat higher. ${ }^{94}$ The most common loophole was for guilds to demand a 'gift', such as the silver spoon worth $13 \mathrm{~s} 4 \mathrm{~d}$ demanded by the Apothecaries and Wheelwrights. ${ }^{95}$ But even fee and spoon together was not a large sum, equating to perhaps ten days wages for an unskilled construction worker. Guild fees in

\footnotetext{
${ }^{89}$ A. Macfarlane, ed, The Diary of Ralph Josselin, 1616-1683 (Oxford: Oxford University Press, 1976), 120, quoted in Pelling, Common Lot, 127.

${ }_{90}$ Minns and Wallis, 'Price of human capital'.

9112 of 26 London guilds surveyed.

92 The Pewterers, Framework Knitters and Clockmakers

9322 Hen VIII, c. 4. 28 Hen VIII, c. 5 banned additional fees for setting up shop etc

${ }^{94}$ Company officials might also extort additional fees for services: 1633 , the beadle and porter of the Drapers were forbidden to demand fees beyond those allowed by the ordinances for binding or making free. Had been demanding $1 \mathrm{~s}$ for app by service, $2 \mathrm{~s}$ by redemption or patrimony, rather than $4 \mathrm{~d}$ allowed. Had been demanding $4 \mathrm{~d}$ for enrolling apprentices, when should have taken none. Arthur Henry Johnson, The History of the Worshipful Company of the Drapers of London, 5 vols. (Oxford: Oxford University Press, 1914-1922).vol. 3, 192, n.2.

${ }^{95}$ Wallis, 'Medicines'; J.B. Scott, Short Account of the Worshipful Company of Wheelwrights, Revised ed. (London: Witherby \& Co, 1961), 15. The Needlemakers charged 10s: The Worshipful Company of Needlemakers of the City of London (London: Robson and sons, 1876), 31; the Basketmakers' spoon was 10s: Henry Bobart, ed. Records of the Basketmakers' Company (London: Dunn, Collin \& Co, 1911), 107.
} 
Sheffield's Cutlers and Lincoln's Tailors were at a similar level. Unusually, moreover, apprentices in London usually paid less than masters' sons who had not been indentured in the guild.

For the remainder of apprentices, their only proof of service was a note from their master or the counterpart of their indentures to indicate that they had finished their term. It demonstrated their freedom from binding contractual obligations and right to work under the Statute, not skill. Certification of apprentices' skills was an innovation that emerged as the state began investing in supplementary training for youths in the late nineteenth century. ${ }^{96}$ With it, and not coincidentally, the state ensured that its subsidy (via funded technical training) paid off across the whole labour market.

\section{Conclusion}

Apprenticeship in early-modern England provided the main form of training outside of farming. It was a massive, relatively open and accessible system that may at times have included a majority of youths who were not employed in agriculture, and was widespread in both town and countryside. Paradoxically, it was made more attractive by a national legal framework that had been intended to keep labour on the land, and it remained central to the creation of vocational human capital through to the first industrial revolution and beyond. It allowed youths to invest in their own productivity in a period where firms were small and few jobs lasted for long. Working to pay for learning lowered credit constraints and allowed youths to immerse themselves in gaining tacit occupational skills. By accepting high rates of premature exits, and establishing an institutional framework to cancel contracts that were proving unsatisfactory to either party, the English system lowered the risks involved in choosing a master, a city, or a career and softened the burden that the exceptionally long terms of service that the Statute of Artificers had created. With few real barriers to entry set by either law or guild regulation, apprenticeship channelled labour from all backgrounds and all regions out of agriculture and into industry and services, and facilitated migration into cities, particularly London, which achieved an extraordinary dominance of urban training; it was a key vector in the extraordinary and precocious process of urbanisation and structural change in England that transformed the nation from an agrarian backwater to an industrial power.

\footnotetext{
${ }^{96}$ W.W. Knox, 'British apprenticeship, 1800-1914', PhD thesis, University of Edinburgh 1980; Charles More, Skill and the English Working Class, 1870-1914 (London: Croom Helm, 1980).
} 
Figure 9.3: Proportion of London and Bristol apprentices resident with their master

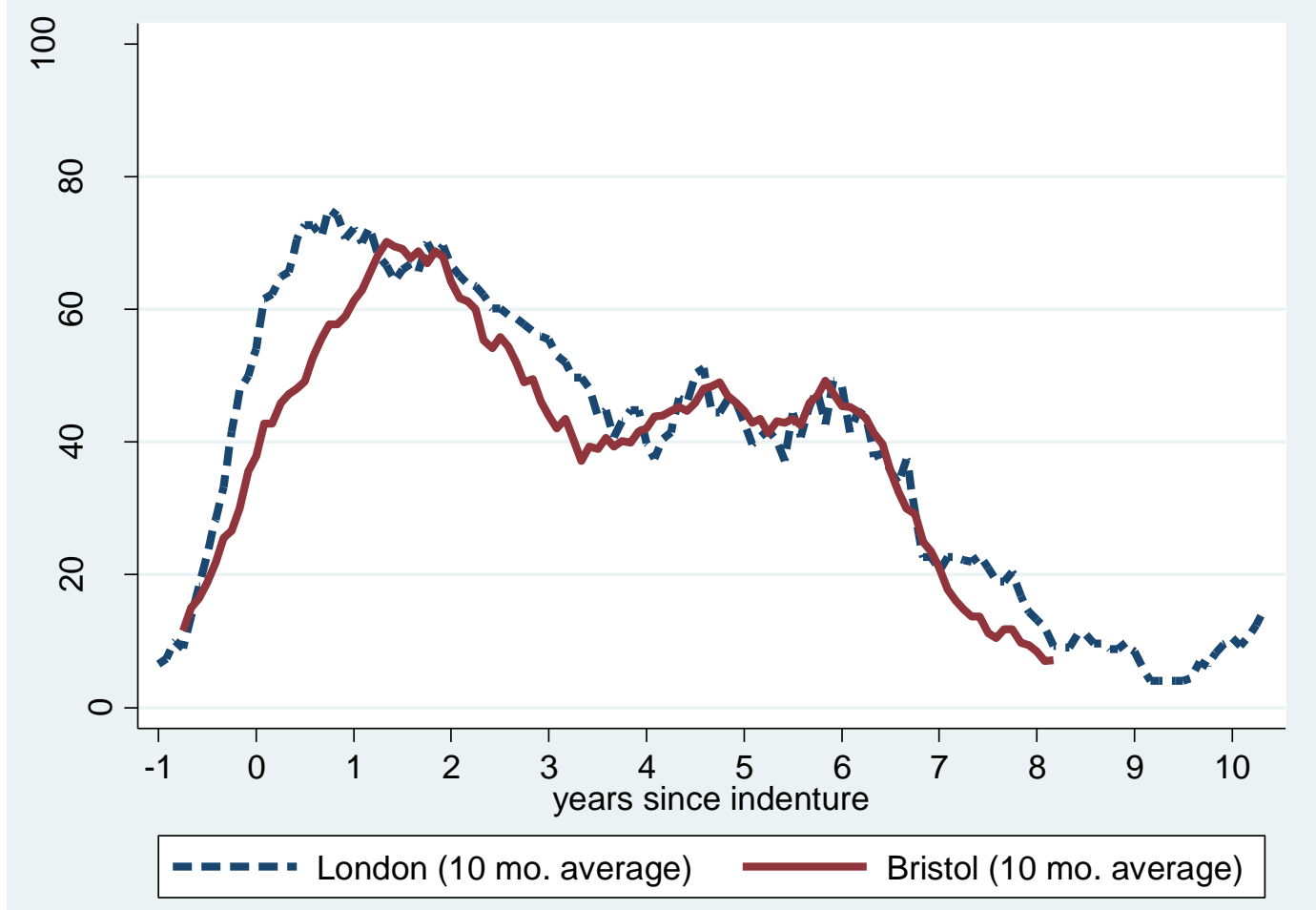

Source: Minns and Wallis, 'Rules and reality'. 